\title{
Exploring Globalization on the Perspective of Female Tea Garden Workers of Bangladesh
}

\author{
Sumaya Khan Auntu
}

\section{ABSTRACT}

The conflict between flat and spiky world is a source of ongoing discourse. There is an abundance of literature explaining how the flat world mocks itself with the spikiness throughout. There is a lack in constructing trust-based relationships, connecting capabilities and amplifying innovation and learning across the spikes. The paper will focus on exploring the real status of the world whether it is flat or spiky on the context of female tea worker of Bangladesh along with analyzing the natural and social scenario of environment and job field of female tea worker in which they are suppressed and their level of consciousness about their rights and privileges. The paper will follow the research question-How do the arguments of flat and spiky worlds fit when tested from the perspective of female tea garden worker of Bangladesh? Furthermore, the paper uses qualitative research method to build arguments beyond the gaps that existing literature provides.

Keywords: Explore, Flat, spiky, Globalization, Workers, Bangladesh.

\author{
Submitted : March 26, 2021 \\ Published : April 16, 2021 \\ ISSN: $2507-1076$ \\ DOI: $10.24018 / \mathrm{ejbmr} .2021 .6 .2 .830$ \\ Sumaya Khan Auntu* \\ Bangladesh University of Professionals, \\ Dhaka, Bangladesh. \\ (e-mail: sumaya.bupir17@gmail.com)
}

*Corresponding Author

\section{INTRODUCTION}

"Never accept the world as it appears to be, dare to see it for what it could be"- a saying by Dr. Harold Winston inspires mankind to question about their existence again. The technological revolution of the $21^{\text {st }}$ century certainly flattened the round world through the tools of global connectivity. But these may be illusions through bare eyes while the world may not be so flattened up as it seems to be. The more someone looks closely, the less he sees and to reveal the mystery, two pioneers came up; Thomas L. Friedman, an American journalist and author, currently working for the New York Times and Richard Florida, professor of public policy at George Mason University, who appear to clash with each other. The flatness and spikiness that has been mentioned are static metaphors of space which means they define a point in time. There is zero possibility to find a generalized logic everywhere. This paper takes the case of female tea worker in Bangladesh as the evidence to test the hypothesis of the three proponents. Being a developing lower middle-income country and having one of the fastest growing economies of the world, Bangladesh makes a very interesting case to shed light on. However, the evidence from female tea worker in Bangladesh is also context specific and accrues different outcomes at different point.

\section{OBJECTIVES OF THE STUDY}

The main theme of this study is to explore the real status of the world whether it is flat or spiky on the context of female tea garden worker of Bangladesh. Along with the main goal, there are two specific objectives have been set for identification of real scenario, as follows:

1. To find out the relevance with flatness and spikiness in the context of female tea garden worker in Bangladesh.

2. To find out natural and social scenario of Environment and job field of female tea garden worker in which they are suppressed.

3. To assess the female workers' level of consciousness about their rights and privileges.

The paper will focus at first on the arguments of three specific proponents of globalization and then analyze the recent conditions of female tea garden worker in Bangladesh based on these arguments to find out which one suits best. The findings of this paper will be helpful in the scholarly circle as it relates the theoretical positions of scholars with the scenario in Bangladesh whereas, the policy circle will get the insights how female tea garden workers in Bangladesh are performing in the age of competitiveness and how to implement strategies to make them more and more competent in the race.

This paper is based on the following research question:

- How do the arguments of flat and spiky worlds fit when tested from the perspective of female tea garden worker of Bangladesh? 
To find the answers to this question the paper will have two secondary questions:

- How do the arguments of flat, not flat and spiky worlds stand against each other?

- How does the scenario of female tea garden worker of Bangladesh fit into the propositions?

\section{HYPOTHESIS}

This is the age of globalization. There is both optimism and skepticism around the prospects and contributions of globalization. Scholars are divided and there is no chance of taking a side in this debate as the statistics and evidence goes both ways. It is necessary to identify which one of the arguments is on the right side in most places. Moreover, Bangladesh is developing at a high rate but still has a long way to go. There are literature talking about development opportunities and suggestions for the future but there is lack of research relating the position of female tea garden worker in Bangladesh with the concepts of optimism and skepticism of the scholars. So, testing the case of female tea garden workers based on the arguments will be helpful to analyze the possibilities, prospects and suggestions for the future and certainly will be an addition to the existing knowledge.

\section{RESEARCH METHODOLOGY}

The Paper analyzes three scholarly positions on the prospects of globalization and tests them in relation to female tea garden workers of Bangladesh. Therefore, the research has taken resources from the open sources including journals, newspapers and so on. However, a mixed analysis has been provided to compare the evidence and test them with the hypotheses.

\section{ANALYSIS \& DATA PRESENTATION}

The book "The World Is Flat" attracted a bunch of people supporting in favor of globalization where the focus is on creation of 'level playing field' for all in the global economy [4]. Friedman added in his book that Berlin Wall Fell (September 1989) as the first flattened incidents which not only meant the end of Cold War but also aided the establishment of global connectivity which flattened the world [4]. He also mentioned "Triple Convergence" of the creation of level playing field by establishment of trade and communications, the merger of the new playing field through innovative ways and bringing diversification in the arena and bringing each and every person in this world on this playing field [4]. Seven billion people in the world are now part of global connection where country like Russia and China also opened up broadly for prosperity [8]. As example, Bangladesh as a middle power developing country has also participated in this race and doing quite well.

Pankaj Ghemawat, professor at the Harvard Business School, put forward the strongest arguments for the idea that the world is not flat. As mentioned earlier, the more someone looks, the less he sees [6]. Because everyone only observes the magic of internet and modern high technologies but how much access one has does not matter much. Not everyone is getting full access of the rewards of high technologies like Ghemawat asserts only a fraction is under globalization [6]. For example, while Chowdhury, Hasan \& Karim [15] visited in two tea gardens of Moulvibazar district and revealed that on the water supply and sanitation conditions (WATSAN condition) of garden's workers is not sound [14]. When the world is witnessing the development of 'robotics', then tea garden workers of Sylhet does not have minimum health and hygiene facilities.58\% people were getting improper tube well and latrine facilities and among them $80 \%$ were illiterate [14].

The world may be flat-like but still not as smooth as the viewers like Thomas Friedman suggests. So, it can be said that the stunning magic of technology is merely an exaggeration of the supporters of Thomas Friedman [6]. Justin Fox, an American Journalist, also supports the idea that the world is not flat [7].

On the other hand, Richard Florida suggests that location plays a vital role by variety of measures which make the world spiky [5]. It means activities, particularly the economic ones, are congested in a relatively few geographical locations. Friedman's idea matches with the level playing field for peaks highly and merely a part is for the hills while valleys remain in the dark. The equal playing field is not equality for all and it cannot be until this discrimination is resolved [5]. A female tea garden worker in Bangladesh gets wage of tk. 45 for a day's work which is already below average and inhuman to the workers of Bangladesh as a democratic country [2]. On the other hand, it is very surprising for an elected government by people in allowing such injustice for years. The owners of tea companies are making profits in dollars but have been depriving their workers of minimum reasonable wage comparing other day laborers, garment workers, peasant farmers who all are getting tk. 200-400 per day in other side of Bangladesh [13].

Barakat et al. (2010) launched an assessment for UNICEF, Bangladesh to determine the actual situation of female tea garden worker of Bangladesh in terms of their health, education, social protection, and dignity [13]. The study shows a miserable condition of children and women workers than their peers those are engaged in other sectors like peasant farmers, garment workers of Bangladesh while the owners of tea garden are making huge amount of profits [14]. The effectiveness of remittance in the economy of Bangladesh has only become possible due to the process of globalization [14] But on the context of female tea garden worker in Bangladesh that will show skepticism as well. On the other hand, there are works which provide with the basic arguments for this paper, and they will be discussed in the next part.

Globalization is the speed up of movements and exchanges of human beings, goods, and services, capital, technologies, or cultural practices all over the world [1]. Globalization has interconnected the world in such a way that openness of free trade system makes the business easier. People can conduct business in the global forum sitting inside their own houses [3]. It is obviously the flatness of the world, but it has some spiky effects as well. Globalization here is the independent variable. Due to the blessing of globalization in free trade it is found that unsustainable high consumerism, precarious, low wages work create inequality between the male and female tea workers which may result in future social conflicts 
[1]. Alongside because of anti- democratic characteristics of global capitalism government of Bangladesh are unable to negotiate all those issues with the capitalists and it finally results in deplorable living condition of female tea worker which is a dependent variable [1].

TABLE I: DEPENDENT AND INDEPENDENT VARIABLES [1]

\begin{tabular}{|c|c|c|c|}
\hline $\begin{array}{c}\text { Independent } \\
\text { Variables }\end{array}$ & Flatness & Spikiness & $\begin{array}{c}\text { Dependent } \\
\text { Variables }\end{array}$ \\
\hline Globalization & Free Trade & $\begin{array}{c}\text { a.High } \\
\text { Consumerism } \\
\text { b. Anti Democracy } \\
\text { c. Precarious } \\
\text { d. Low wages work } \\
\text { e. Social conflict } \\
\text { f. Inequality }\end{array}$ & $\begin{array}{l}\text { Deplorable } \\
\text { living } \\
\text { condition of } \\
\text { female tea } \\
\text { worker }\end{array}$ \\
\hline
\end{tabular}

With the blessing of global capitalism, openness of free system worldwide has made the world economy smaller [3]. Sitting at one side of the world one can communicate with each other. With the huge amount of GDP growth, it is creating havoc on the lives of ordinary and defenseless people and community. As the ideology of global capitalism undermines the public goods which is more harm than good [1]. The mass consumerism required by global capitalism is unsustainable [1]. To respond with this mass consumerism of tea production female tea garden worker of Bangladesh are not fortunate enough to take their maternity leave which has crossed all probable boundary of humanity [3].

Global capitalism is a development tool that is antidemocratic in nature [1]. It fosters precarious and low wage work. In tea garden it is witnessed that tea workers are getting wages at tk. 45 each day [15]. Here owners of tea gardens are earning a good amount of profit through the free trade system, but they are not considerate enough for their workers as a result the rich become richer, the poor become poorer [14]. Though the male worker somehow adjusts with this mass consumerism of tea production, but it results in quite difficulty for the females to cope up with this as after eight hours of working schedule they need to perform in the household chores [13]. Moreover, they are unable here to maintain minimum level of hygiene, so there remains probability for them to be affected by any of the diseases [14]. Day by day people are becoming educated and conscious about their citizen and human rights. If the phenomenon is going on like this, any day it may result in social conflict.

Seven billion people in the world are now part of global connection where country like Russia and China also opened up broadly for prosperity. In his work, Thomas Friedman argues that the world is getting more connected day by bay in such a way that eradicates shortcomings of communication, business, trade, job opportunity amongst other things. For example, in his book, he refers to the ability of businesses to set up their work offshore i.e., someone can work from any corner of the world at any moment he wants according to his choice of ease [4].

Friedman tried to show that, the next emerging player in the field can be anyone, may be from Bangladesh or may be from Nigeria or any remote place that was never a hot favorite before [4]. But the fact is worth concerning whether the playing field became level for all or it created equal level for certain portion of the population [12].
On the other hand, everyone is not getting full access of the rewards of high technologies like Ghemawat asserts only a fraction is under globalization [6]. Today people of the developing countries like Bangladesh are getting introduced to high-tech instruments like mobile phone, computer, VR (Virtual Reality), 3D movie experience etc. But still, they lack many resources and facilities that are readily available in developed countries [15].

Justin Fox, an American Journalist, also support the idea about globalization is that the pace of it is still pretty slow. There is still a long time to reach the peak to call the world 'flat' [7].

Richard Florida concentrates on a particular quote from the best-selling book of Thomas Friedman: "In a flat world you can innovate without having to emigrate" and suggests that location plays a vital role by variety of measures which makes the world spiky [5].

Friedman's idea matches with the level playing field for peaks highly and merely a part is for the hills while valleys remain in the dark. The equal playing field is not equality for all, and it cannot be until this discrimination is resolved [5]. The population proportion living in urban areas increased to $50 \%$ from $30 \%$ at present in comparison to the 1950s [5]. Cities have always acted as flywheel of innovation, center of growth, founder of monuments and people have clustered here for a new hope in search of economic opportunities. The equal fields are now the fields of cities, but large portions of the world do not know the existence of a playing field. The flat world mocks itself with the spikiness throughout [5].

These debates will be briefly analyzed through exploring the spikiness of the world on the perspectives of the female tea workers of Bangladesh.

For Bangladesh the flattening as well as the spikiness seems true at different moments and debates can last forever. However, there are certain areas where the country needs to develop itself to survive in this global era of competitiveness. Today Bangladesh is the $41^{\text {st }}$ largest economy in the world that is another step for Bangladesh becoming one of the important actors in world economy [11]. Bangladesh is expected to be the $24^{\text {th }}$ largest economy in the world as soon as 2033 by Center for Economics and Business Research (CEBR) in 2018 [12].

The Gross Domestic Product of the country is also increasing at a very fast rate over the years and is set to grow by an $8.13 \%$ the highest ever in the country's economic history [11]. The growth crossed the global average in the 1980s and remained above since then along with all the South Asian countries with lesser fluctuations in the rates. Recently Bangladesh stood first among all the South Asian economies in terms of Foreign Direct Investment (FDI) inflow in 2018 according to World Investment Report 2019 by United Nations Conference on Trade and Development (UNC TAD) [8]. Without the openness of the flow of capital these would have been impossible [9]. Thus, the flattening of the world is in work and it cannot be ignored. But however, statistics alone cannot always express the actual scenario. While according to Oxford Internet Institute (OII) of Oxford University in the UK, $16.8 \%$ people of Bangladesh are engaged in outsourced online works all around the world, a rate which is second only to India on $24.6 \%$ [10]. In this context Bangladesh is in quite better position but on the other 
hand, Tea garden workers are the most deprived sector in Bangladesh, especially female tea garden workers. $80 \%$ of female tea garden worker gives birth of their children at home without the presence of any trained midwife [13]. It is the evidence that female tea garden workers are not provided with minimum health care especially at their pregnancy time [14]. They do not provide with maternity wages properly if they remain on leave during pregnancy time which proves extreme level of inhumanity [13]. Sometimes they have abortion while count hours hard work each day in tea gardens. A female tea garden worker does not get adequate amount of rest and nutrition as a result their child face malnutrition along with many complications [14].

Alongside female tea garden workers are destined to endure patriarchal repression as well in the twenty-first century. They need to deliver all the money of their salary to their husband or father. Being sometimes tortured when they are caught with tk.10/20 of rupees hidden for urgency [13], [14].

TABLE II: SCENARIO OF DOMESTIC VIOLENCE [13], [14]

\begin{tabular}{ccc}
\hline Name of Issues & Yes $(\%)$ & $\operatorname{No}(\%)$ \\
\hline Control over Self & 32 & 68 \\
Income & 6 & 94 \\
Ownership of Property & 92 & 8 \\
Physical Harassment & & \\
\hline
\end{tabular}

Still, they remain silent as women in Bangladesh are growing up with stereotype of social settings; fathers, husbands and sons [15].

Female tea garden workers are such type of victims that their human rights as well as citizenship rights are being fully dishonored and disregarded in terms of negligible payment, unhygienic working environment and behavioral patterns of co-workers. Even they are considered as irrational and unfit economic agency [14].

The wages a female tea garden worker gets is very negligible. They gather almost $50 \mathrm{~kg}$ of leaves in a day and paid only tk. 2 for each. In case of extra work, they are repaid extra tk.0.80 for gathering extra per $\mathrm{kg}$ and can earn only tk.100 per day by their labor of whole day that less than one $\&$ half US dollar [11]. It is proved that the female tea workers of Bangladesh live an inferior standard of life compared to that of the major tea producing countries in the world [16].

An interview conducted by Haider (2019) on a total of eight tea plantation companies, all supplying tea to Unilever. As per given report of workers, they are being harassed on the basis of sex, ethnicity and gender that make violation of ILO code of business principles [13]. In case on any report on the higher authority, the victims need to undergo tough punishment in their working place [14]. The female tea garden workers are subjected to pregnancy tests before employing. In case of positive report of pregnancy test, their medical cards would be stamped as unfit [15].

It is found that female tea garden workers are suppressed in each and every sphere of life starting from family residence to job field [14]. 68 percent of female workers need to deliver their full amount of salary to their family especially to the male persons of their family [15]. 94 percent female tea workers are deprived of hereditary property ownership and 92 percent females are physically tortured and mentally harassed by the people and surroundings [16].
The decision of female is not valued even in case of keeping small size of family when they need to face extra working loads regarding eight hours tea garden duty, cooking and cleaning of house with managing the children. But still, they are surviving under this vigorous condition silently due to their narrow and conservative mind, lack of education and unawareness of their rights and law enforcement [16]. Richard Florida stated that large portions of the world do not know the existence of a playing field [5]. The female tea workers of Bangladesh can be set as evidence how in this flat world, one large portion is struggling for their basic needs.

\section{LiMITATIONS}

This paper is based on secondary data collected from different books, articles, journals and reports of different national and international organizations. Due to COVID-19 pandemic and time limitations, primary data collection was not possible.

\section{CONCLUSION}

While Thomas Friedman and Richard Florida conflicts on the 'flat or spiky' issue, mankind may be living in a world both flat and spiky [7]. Technology has contributed to meteoric rise of the middle class of developing countries like Bangladesh which obviously proves the flattening of the world. But the rays of globalization are not reaching at every door that ultimately raises spikiness [5]. This controversy reminds of the Phillips curve as the flatter the world gets, the more is the chance of emerging spikes [6]. After the comparative analysis, there is no chance to go for one single argument. Both the forces are apparent from the evidence from different perspectives. The arguments of Friedman, Ghemawat and Florida are proved from different lenses with evidence. Taking the national level, the arguments of Friedman seem appropriate but the scenario changes when the internal inequalities are taken into account like the daily struggle of female tea workers in Bangladesh who are deprived of their basic human rights and labor rights.

\section{RECOMMENDATIONS}

Most of the time, in the age of globalization, the priority is national development and individual profit generation. The nations are competing against one another to get forward in the race [8]. But collaboration in terms of inequality reduction and poverty alleviation has been ineffective. Every person is busy in individual profit generation [9]. The owner of tea garden does not have time to think about his workers. They value only the word 'loss and profit'. Such a model where competitors turn into collaborators is seemingly rare now-adays [10].

Few policies are recommended to overcome this spikiness on the perspectives of the female tea workers of Bangladesh.

1) Adaptation through building trust-based relationships, connecting capabilities and amplifying innovation and learning across the spikes. 
2) The government can fix the minimum reasonable wage for the female tea workers of Bangladesh to contribute to protection and development of its citizens.

3) The female tea garden workers need to be educated enough to understand their rights and duties properly.

4) They should have developed other skills so that they can use it as earning tools based on requirement.

As a huge amount of 3,55,580 people are working in Tea garden of Bangladesh among them $75 \%$ are female [11]. So, the greatest insight will come from understanding the paradox that the flattening of the world is creating. In a world both spiky and flat, it does not matter which someone believes in rather the belief in change can create a utopia within this world.

\section{CONFLICT OF INTEREST}

The author declares no potential conflict of interest concerning research, authorship or publication of this paper.

\section{FUNDING}

The author receives no financial support for research, authorship or publication of this paper.

\section{REFERENCES}

[1] A. Ambrossini, 'What's wrong with global capitalism?' Skeptic Society Magazine, 2017.

[2] M. Helal \& M. Hossain. (2013). Four decades of economic development of Bangladesh: An assessment, Journal of the Asiatic Society of Bangladesh (Hum). [Online]. 58(2), pp.335-362. Available: https://www.researchgate.net/profile/Md_Amzad_Hossain3/publicatio n/321278555 FOUR DECADES OF ECONOMIC DEVELOPME NT_OF_BANGLADESH_AN_ASSESSMENT/links/5a188ef7a6fdcc 50ade7e5a2/FOUR-DECADES-OF-ECONOMIC-DEVELOPMENTOF-BANGLADESH-AN-ASSESSMENT.pdf.

[3] B. Adhikary. (2011), FDI, trade openness, capital formation, and economic growth in Bangladesh: a linkage analysis. International Journal of Business and Management. [Online] 6(1), p.16. Available: http://citeseerx.ist.psu.edu/viewdoc/download?doi=10.1.1.686.5446\& rep $=$ rep $1 \&$ type $=$ pdf.

[4] T. L. Friedman, "The world is flat: A brief history of the twenty-first century", Macmillan, 2005.

[5] R. Florida, "The World is Spiky: Globalization has changed the economic playing field, but hasn't leveled it", Atlantic monthly, 296(3), p.48.

[6] P. Ghemawat. (2007). Why the world isn't flat. Foreign policy. [Online]. pp.54-60. Available: https://www.jstor.org/stable/25462146.

[7] J Fox, "The world is still not flat," Harvard Business Review, 2014.

[8] "United Nations Conference on Trade and Development," World Investment Report, 2019.

[9] Youth turns millionaire working as freelancer, inspires others. (2019). The daily Star. [Online]. Available: https://www.thedailystar.net/country/news/youth-turns-millionaireworking-freelancer-inspires-others-1732912.

[10] I. H. Ovi. (2017). Freelancers turn Bangladesh into a hub for ICT outsourcing. Dhaka Tribune. [Online]. Available: https://www.dhakatribune.com/career/2017/09/20/freelancers-turnbangladesh-hub-ict-outsourcing.

[11] "Global Wage Report 2018”, International Labour Organization (ILO), 2018

[12] Bangladesh Bureau of Statistics. (2016), Household Income and Expenditure Survey (HIES) [Online]. Available: http://203.112.218.65:8008/WebTestApplication/userfiles/Image/Late stReports/HIES-10.pdf.

[13] A. A. Haider. (2019). What the rising GDP and per capita income are not telling us., Dhaka Tribune. [Online]. Available: https://www.thedailystar.net/opinion/finance/news/what-the-risinggdp-and-capita-income-are-not-telling-us-1726945.
[14] A. Barkat, G. Mahiyuddin, N. Shaheen, A. Poddar, A. Osman, M. Rahman, \& R. Ara, "Assessment of the situation of children and women in the tea gardens of Bangladesh", Human Development Research Centre, Mohammadpur, Dhaka.,2010.

[15] M.A. I. Chowdhury, G. M. J. Hasan \& M. A. Karim, "A Study on Existing WATSAN condition of Two Tea Gardens in Moulvibajar," Journal of Enviromental Science \& Natural Resources, 4(2), pp. 13-18, ISSN 1999-7361, 2011.

[16] H. Enamol, "Deplorable Living Conditions of Female Workers: A Study in a Tea Garden of Bangladesh", American Journal of Humanities and Social Sciences, Vo1. 2, No. 2, 2014, p.121-132.

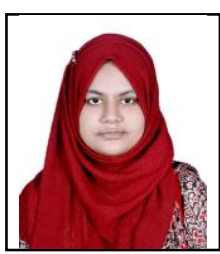

Sumaya Khan Auntu was born in Tangail, $11^{\text {th }}$ of November, 1996. Currently, she has completed her Bachelor of Social Sciences (BSS) in International Relations at Bangladesh University of Professionals, Dhaka, Bangladesh. She had completed her internship from Family Planning Association of Bangladesh, Dhaka. Her preferable areas of interest are Crisis Management, Organization and Health Management, Peace and Conflict Studies, International Development, UN Peacekeeping Operations, International Relations in Political Thoughts, Migration Studies, and Public Policy. The work, she has represented here is related to organization studies and health \& safety management. 